Research in Social Sciences

ISSN: 2641-5305

Vol. 2, No. 2, pp. 29-34

2019

DOI: $10.53935 / 2641-5305 . v 2 i 2.13$

(C) 2019 by the authors; licensee Academic Publishing Group

\section{Exploring the Debate of Free Public Tertiary Education in Mauritius}

N K Betchoo: Dean of Faculty, Business and Management, Universite des Mascareignes, Mauritius

\begin{abstract}
This paper comes at the right moment when the Prime Minister of Mauritius declared on the 1st January 2019 that there would be free tertiary education in public universities of the country. This measure was instinctively considered as populist due to the imminence of forthcoming elections in the country and met with criticisms from various parties. Seen from a different perspective, the provision of free tertiary education in public universities might be a sequel to the already existing free education provided at the primary and secondary levels. This could be a right measure in the sense that education is extended up to the tertiary where the country might need graduates at a strategic level. There might be reservations like the high level of unemployment among the youth, around 30\% and the need to find immediate measures to curb this problem. Otherwise, free university education has to become a well-framed concept today where it should prepare the youth to face the challenges of tomorrow in a world of constant evolution. The paper sums up with a perspective of university education after an analysis of the debate surrounding free tertiary education in Mauritius.
\end{abstract}

Key words: Free tertiary education, Debate, Views, Chronology, Public universities, Mauritius.

\section{Introduction}

Government recently announced free education at the tertiary level for all public institutions in Mauritius. This decision was viewed in different ways from the various stakeholders ranging from a populist to a social measure regarding students having little means of affording tertiary education. This paper actually adopts a rational and objective approach in explaining that tertiary education in public institutions was basically free from its inception and that today's decision to extend free education up to the tertiary level remains logical although this demands an additional financial input of some Rs 600 million from the government along with a strategy to sustain such a policy. It firstly explores the concept of free tertiary education in a brief literature review to show that although it is a generally challenging strategy to adopt, it might have its validity since its most daunting element remains the financing of higher education.

The paper develops the debate by explaining the free tertiary education issue from a chronological perspective based on the author's personal research published in a local newspaper. It depicts how tertiary education was initially free but could not be sustained due to the high financial burden incurred therein. Since January 2019, the Mauritian Prime Minister has announced free tertiary education in public institutions and this statement has led to both favourable and mixed comments from onlookers. Such information has been selectively included to provide a summary of key debates on the issue.

The final part of the paper considers certain reflection on free tertiary education and how this is likely to impact the present and future generations in Mauritius. The next heading describes some literature on free tertiary education.

\section{Literature Review}

The United Nations' International Covenant on Economic, Social and Cultural Rights Article 13 (1) states: "The States Parties to the present Covenant recognise the right of everyone to education. They agree 
that education shall be directed to the full development of the human personality and the sense of its dignity, and shall strengthen the respect for human rights and fundamental freedoms."

It also states that "education shall enable all persons to participate effectively in a free society, promote understanding, tolerance and friendship among all nations and all racial, ethnic or religious groups, and further the activities of the United Nations for the maintenance of peace."

Dhillon (2013) states that free education also has its implications economically. A population that is better educated is able to find better jobs with better pay, and directly contributes back to the country in the form of taxes, which provide for the funding of free education in the first place.

Reiff (2014) purports that free education satisfies the concerns of the left: everyone would be able to get a high quality higher education no matter what economic resources they or their families currently enjoy. No longer would poor students have to choose between working long hours at menial low-wage jobs to finance their education, thereby jeopardising their ability to perform well in or even complete their courses, and taking on large debts they cannot begin to pay.

The Conversation (2016) points out that education as a public good should be regarded as essential to the development of citizens in a democratic society. Public resources must be used in ways that can support and engender ideas and practices which enhance cooperation, collegiality, social sharing, social responsibility, caring and social equalisation. This sort of education can help to reconceptualise the goals of a socially just society. It can reorganise social relations more fundamentally than the current system does.

The goal of public quality education is to bring all of society, not just the "historically disadvantaged", into the process of social transformation. It involves both those who are wealthy and those in poverty. This allows a process of genuine social reorganisation to start, and enables South Africa to address the structural characteristics of social inequality (The Conversation, 2016).

Cloete's view is interesting in that he gives a different interpretation to the concept of free education in that it should not be necessarily free for everyone. According to Cloete (2015), for the rich, higher education in South Africa is a bargain, for the gifted poor it is affordable through financial aid, but if the middle is missing then. The 'missing middle' is not only the backbone of higher education worldwide, but a productive and well-educated middle class is also the glue that holds society together. 'Free Higher Education' sounds revolutionary and is an appealing mobilising 'cry'. But in a developing country it is financially, empirically and morally wrong - the poster should read "Affordable higher education for all" - with a clear understanding that affordable means different costs for different groups in society.

Govindarajan and Desai (2013) state that there is a need for transformational innovations to stop this train wreck. A new business model will only emerge through continuous discovery and experimentation and will be defined by market demands, start-ups, a Silicon Valley mind-set, and young technology experts. In the near future, higher education will cost nothing and will be available to anyone in the world. Degrees may not be free, but the cost of getting some core education will be. All a student needs are a computing device and internet access.

\section{Free Tertiary Education at the Beginning in Mauritius}

Prior to independence, education was free only at the primary level while secondary schools were feepaying except for a few national colleges like the Royal College Port Louis, Royal College Curepipe, Queen Elizabeth College and the John Kennedy College, which were reserved for Junior Scholarship achievers eligible for the selective places in these top brass institutions. All other colleges charged school fees which excluded many potential students from achieving secondary education. In 1977, secondary education was declared free and promoted entry to secondary schools to a huge number of students all over the country. Little might be known of tertiary education at that time since Mauritius had a single university, the University of Mauritius (UOM) created in 1965 and developed from the School of Agriculture. Courses offered at that time were free albeit administrative charges in developing sectors like Agriculture and public sector management (Betchoo, 2019). Students achieving 'A' level passes chose to study abroad particularly in the United Kingdom, France and India, the latter being the most favoured attraction for students capable of affording high quality tertiary education at comparatively lower prices. Incidentally, the local university maintained a low profile with a modest number of courses offered which were free on a full-time basis.

Research in Socials

Vol. 2, No. 2, pp. 29-34

2019

DOI: $10.53935 / 2641-5305 . v 2 i 2.13$

Email: nbetchoo@udm.ac.mu

Funding: This study received no specific

Article History:
Received: 10 January 2019

Revised: 15 February 2019

Accepted: 1 March 2019

Published: 13 March 2019

(1) 2019 by the authors; licensee Academic

Publishing Group

| 30 


\section{Post-Secondary Training by Local Institutions}

Apart from the UOM, free tertiary education was quite rare except that the Mauritius Institute of Education (MIE), created in 1973, offered teacher training courses whereby students were already enrolled as trainee teachers but pursued pedagogical training beyond secondary schools in order to be equipped to teach both in primary and lower secondary schools. There was also the setting up of the Industrial and Vocational Training Board (IVTB) presently MITD by 1987 which allowed students to be trained freely at the beginning. With Mauritius stepping to a newly industrialised country in the mid-1980s, there was a growing demand to train the community in order to develop competences needed to propel Mauritius to a middle-income country status.

\section{Polytechnic and Free Post-Secondary Education}

If the MIE trained already recruited trainee teachers, student education was so far limited to the UOM only whereby after completing a diploma or degree course, students applied for a job on their own. By the end of the 1990s, degree courses were awarded by the UOM through the creation of additional faculties besides those of Agriculture and Law and Management. Student enrolment increased with a wider range of courses offered. The fact that students, during the economic boom, were employable just after completing university created a greater demand for university seats. The UOM could not accommodate an overwhelming demand for seats by the mid-1990s where supply was limited and obviously grew competitive in certain faculties.

'A' level students who did not get a seat could either opt for fee-paying education abroad or seek distance learning. Incidentally, polytechnic education modelled upon the Singapore education system was developed in Mauritius in 1995 through the Droopnath Ramphul Polytechnic and three years later, the Institut Supérieur de Technologie, both now campuses of the Université des Mascareignes. This became an opportunity in furthering tertiary level education in these two institutions which were obliged to remodel their initial programme to a University diploma. Post-secondary training encouraged students to afford such a valuable qualification in two years' time freely with administration fees mounting up to Rs 7000 for two years. Evidently, graduates from these polytechnics entered the job market and a few others chose to join a top-up programme at the UOM or any foreign university.

\section{The Fee-Paying Concept}

With an increase in enrolment, two new universities were developed. The second public university was the University of Technology, Mauritius (UTM) created in 2000 following the merger of SITRAC and MIPAM into a university. The UTM became the first fee-paying university with education fees mounting up to Rs 30-40,000 per academic year. The decision came from the fact that a greater student intake incurred heavy financial investment from the government while more public secondary schools were built around the country. With focus on secondary education, tertiary education became partly fee-paying in most public universities.

It should be noted that tertiary education was under the aegis of the Ministry of Tertiary Education and Research between 2010 and 2014. During that time, the Open University was created and enacted as a public university in 2010. It was earlier the Mauritius College of the Air (MCA) which was limited to distance education up to the secondary level. The Open University provided and still offers fee-paying education with an enrolment that has substantially increased over the years.

At the same time, private tertiary institutions started their operations in Mauritius with universities setting up local branches. Earlier, Edinburgh Napier University launched a distance-learning MBA but ceased afterwards. New universities that operated locally were Middlesex, Greenwich followed by a few others. With a decision to have 'one graduate per family' as decided by the previous government, university demand increased substantially promoting the setting up of local institutions providing fee-paying degree courses like Rushmore Business School, Aberystwyth University and a lot many others including French-based university system at Unicity, Flic-en-Flac.

\section{Back to Free Tertiary Education}

The present decision to extend free education up to the tertiary level in public universities and institutions? 
since the development of public schools in Mauritius followed by free secondary education in 1977. Apparently, seen from the chronological perspective, tertiary education was free for full-time students between 1965 and 2000 and it is just since two decades that it has become fee-paying. In practice, there is some logic behind this policy because there are still students from the low-income group who want to enter a university but are prevented from doing so due to financial constraints. Families having more than one ward attending a university do face further financial burden. There is furthermore the need to have a critical mass in higher education to meet the future needs of the country.

It is clear that a lot of debate evolves around the topic and, in a democratic setting, all contributions are welcome. However, university access should not be hurriedly considered as a 'grassroot levelling'. All public universities accept a minimum of 2 ' $\mathrm{A}$ ' levels meaning that only full HSC passes are eligible for free university education. This entry requirement is at par with international university entry requirements and the fact of offering free tertiary education to HSC passing students is fairly reasonable. Definitely, selection will be also a determining factor in getting a university seat and even choices for the preferred courses will remain competitive. The future depends on the quality of tertiary education that students expect to benefit from the free public university but that's another question to debate. Some views are now developed in the coming subheading.

\section{Contemporary Views on Free Tertiary Education}

From this standpoint, the views of free tertiary education were assessed from stakeholders concerned. An initial perspective was to firstly expose views in favour of free tertiary education followed by those that were against such a concept. The findings were published information selected from different media in Mauritius and they were carefully selected, translated from French to English and also purported. The views are elaborated below.

\section{Positive Views on Free Tertiary Education in Mauritius \\ 9.1. The Prime Minister's Point of View}

"The future of the population and the country is in the hands of a youth. The wealth of Mauritius is its population. It has to be prepared to deal with the next 50 years. That is why, as of the beginning of the 2019, education in public tertiary institutions will be free for Mauritians in search of a certificate, a degree or a diploma. The decision will be for full-time and part-time courses. (Deena, 2019) "

"14 000 Young people will get job opportunities and will benefit from training. The Free university is only the foundation of a larger ambition. "

The head of the government has drawn up a list of measures for the development of young people, including free tertiary education. But the prime Minister went further in his argument, emphasising programmes to reduce youth unemployment, among the youth employment programme, the youth Service programme, the National Skills Development programme, among others (Radio One, 2019).

\subsection{Minister of Education's Point of View}

The Minister of Education says that the goal of free higher education is "to alleviate the burden" of those who are struggling to find the funds necessary for their children to be able to enter higher school. According to her, this initiative aims to create equity among the Mauritian population, adding that finances should not be an obstacle to education.

She pointed out that the government has always put the emphasis on education and has never hesitated to invest fully. She added that all the measures announced by the Prime minister since his tenure on education are beginning to take shape, describing some historical measures.

The Minister added that with this initiative, the Mauritian high hand skills would now be assured, arguing that we must have people trained in all new emerging niches, such as technology and others (Minority Voice, 2019).

\subsection{Tertiary Education Commission's President Point of View}

Reacting to the government's decision to make tertiary studies free, the president of the Tertiary Education Commission (TEC), Surendra Bissoondoyal, says: "It is good that we have an education Free service. We are 
moving in the right direction. In this context, he stresses the need to wait for the criteria to be established by the Government."

On the other hand, he says, "at the same time we will have to give our young people an education that would be more work-oriented."

In this perspective, the president of TEC maintains that it is imperative to accentuate on polytechnic education by advancing the argument that the future lies in technology. "If all students are pursuing graduate studies in the same sector, we will end up with a supernumerary number of graduates in a single field." As a result, we must be careful,"maintains the TEC president (Inside News, 2019).

\section{Opposing Views on Free Tertiary Education in Mauritius \\ 10.1. Opposition Party Leader's Point of View}

"We are for free tertiary education but we condemn this announcement made without preparations" said Bérenger. In his view, Paul Berengér recalled that in 1976, the announcement of free secondary education, also made "without preparation causing millions of rupees of wastage". He pointed out that "the public must not forget that there is nothing free because it is the public that pays." He said that many questions remain unresolved regarding the application of free tertiary education. And that in haste, "some institutions have been forgotten like polytechnics.“(Express, 2019)

\subsection{Former Minister of Tertiary Education's Point of View}

Rajesh Jeetah, former Minister of Tertiary Education, wonders how the government will do to accommodate an influx of students on the same campus, if all those who have successfully completed their HSC exam want to pursue courses at the University of Mauritius. Rajesh Jeetah says he doubts the government's intentions as to the interest of young people.

"No studies were undertaken before offering free tertiary studies. There was no action plan. It is only now that the authorities will find the means to implement this project. It is a crime against Mauritian youth, " said Rajesh Jeetah. (Fareedun, 2019).

\subsection{Former Journalist and Social Onlooker's Point of View}

Joël Toussaint, former journalist and social onlooker, explains that Mauritians invest big in education. "The problem with our education system is that we cannot differentiate between a pedagogical approach and an educational project. Everything is distorted since the primary cycle, " he assures.

"The educational project is essentially political and the purely administrative pedagogical project. If we carry out an educational project from a progressive policy, we have a social mobility. If you do an educational project with a conservative policy, you have social reproduction. Policies will never be able to define an educational project," he concluded (Toussaint, 2018).

\subsection{Sunday News Editor's Point of View}

According to Dawood (2019), statistics show that the unemployment rate among young people under the age of 30 is dramatic enough for a country like Mauritius.

"The following analysis derives from statistics Mauritius each year. For 2017, the number of unemployed who had already completed their higher education was 9700 , or $23 \%$ of the total number of jobless. In the third quarter of 2018 , this segment accounted for $26.4 \%$ of unemployed. This is the great concern of the education sector observers in the country. For them, for this measure to be a success, the government must find a complementary measure to ensure job creation." (Dawood, 2019).

\section{Reviewing the Perspective of Effective Tertiary Education}

Apart from direct comments taken from observers, it was important to see how editorialists and opinion leaders might react to the concept of free tertiary education.

Mohamedbhai (2019) comments that essentially, free tertiary education will not benefit those who are really in need, the students from low-income families who often drop out of school because of poor performance or having to work to support the family. A targeted approach aimed at providing support to those really in need and using affirmative action for admission to tertiary institutions would have been much more effective and less costly. 
In a nutshell, excerpts from "A culture of curiosity" reveal some insightful information. Patel (2019) states that Mauritius has the merit of having realised that education is crucial to ensure the technological, economic, social and cultural growth of a country. To maintain itself, and claim to develop further in this world become ultra-technological and ultra-competitive, it is no longer under-trained and obedient arms that we will need. It will be of ultra-trained arms, and spirits.

We are now living in a world that is moving at high speed, where it is expected that technological developments will quickly remove certain trades. Thus, according to a study by the Economic Institute Sapiens made public in August 2018, five professions should become obsolete in the next twenty years, namely those of accountant, cashier, Warehouseman, bank or insurance employee, Executive Secretary.

More than giving skills in specific areas, education for the world of tomorrow will have to train people able to adapt to different realities, to move from one domain to another. For it will no longer be for this generation to make a career like the previous ones. Trades will disappear, and for those who come to school today, other trades that we have not yet thought of today will have appeared when they come out. Hence the need for an education that leads to curiosity, imagination, versatility, adaptability, innovation, creation (Patel, 2019).

\section{Conclusion}

The debate on free tertiary education in Mauritius has immediately raised concerns from the different stakeholders concerned. From a first instance, it is considered as a populist measure with regards to the haste of the announcement of the idea by the Prime Minister while the concept of free further education did not exist in its present agenda. The measure might have been decried but there are reasons to believe in making such education free especially when it regards families from lower-middle backgrounds that might not have access to such education. It is also something welcoming for the young generation that aspires for higher learning and might have been debarred from it. This might not also mean that education should be limited to universities only as polytechnics and other related institutions might provide broader learning opportunities. Further discussion might focus on the challenge of providing free tertiary education in public institutions in Mauritius namely with regards to quality, efficiency and effectiveness. For the time being, teething problems about the implementation of the decision may have to be sought.

\section{References}

Betchoo, N. (2019). Chronology of free public tertiary education. Le Mauricien, $19^{\text {th }}$ January 2019.

Cloete, N. ( 2015). The flawed ideology of 'free higher education. University World News, 6thNovember 2015.

Dawood, M. (2019). Free tertiary education: Are we about to increase the number of unemployed graduates? Sunday News, $6^{\text {th }}$ January 2019.

Deena, M. (2019). Free tertiary education since 2019, L'Express, $2^{\text {nd }}$ January 2019.

Dhillon, R. (2013). Free higher education: Making education accessible to all. The Rakyat Post, $27^{\text {th }}$ December 2013.

Fareedun, B. (2019). Free tertiary education: An electoral announcement without preparation. Rising News, $5^{\text {th }}$ January 2019.

Govindarajan, V. \& Desai, J. (2013). Should higher education be free. Harvard Business Review, $5^{\text {th }}$ September 2013.

Inside News, (2019). We are moving in the right direction. $8^{\text {th }}$ January 2019.

Express, L. (2019). The MMM is in favour of free tertiary education but... as told to Arline Groeme Harmon, $12^{\text {th }}$ January 2019.

Minority Voice, (2019). Free tertiary education, the State will disburse Rs 600 million, $12^{\text {th }}$ January 2019.

Mohamedbhai, G. (2019). What are the implications of free public tertiary education? University World News.

Patel, S. (2019). For a culture of curiosity, Week-End, 14 ${ }^{\text {th }}$ January 2019.

Radio One, (2019). Free tertiary education is just a start, $14^{\text {th }}$ January 2019.

Reiff, M. (2014). How we could solve the riddle of higher education funding. The Guardian, 13 Feb 2014.

The Conversation, (2016). Quality, free university education is necessary - and possible, $28^{\text {th }}$ January 2016.

Toussaint, J. (2018). Free tertiary education in the loop, Defi Media, $8^{\text {th }}$ July 2018. 